Article

\title{
Linking Transformational Leadership, Absorptive Capacity, and Corporate Entrepreneurship
}

\author{
Imran Shafique ${ }^{1, *}$ and Masood Nawaz Kalyar ${ }^{2}$ \\ 1 Department of Management Sciences, COMSATS Institute of Information Technology, \\ Lahore 54000, Pakistan \\ 2 Lyallpur Business School, Government College University Faisalabad, Faisalabad 38000, Pakistan; \\ masood.kalyar@yahoo.com \\ * Correspondence: imranshafique@ciitlahore.edu.pk
}

Received: 19 December 2017; Accepted: 22 March 2018; Published: 27 March 2018

\begin{abstract}
This study aims to analyze the nexus between transformational leadership and corporate entrepreneurship through an integration of dispersed scholarly work on transformational leadership, absorptive capacity, and corporate entrepreneurship under one framework. A survey method was employed for the collection of data from small and medium-sized enterprises (SMEs) of Pakistan. The data were analyzed using structural equation modeling (SEM) technique to empirically test the hypotheses. The results demonstrate that transformational leadership positively affects corporate entrepreneurship and its dimensions-namely, innovation, new business venturing, self-renewal, proactivity, and risk-taking - both directly and through absorptive capacity. The potential of transformational leadership to influence corporate entrepreneurship via absorptive capacity added additional interesting substitutes. Future studies may produce novel insights by examining different leadership styles, settings, or utilizing qualitative technique. Firms should invest to initiate transformational leadership training programs for their managers. Additionally, if these firms are aiming to promote corporate entrepreneurship, they should focus on hiring managers that have attributes of transformational leadership. Furthermore, they should also invest in absorptive capacity to utilize outside knowledge for the enhancement of entrepreneurial activities. This study exploits research work on the relationship between transformational leadership and corporate entrepreneurship in a novel way; it investigates the dimensions of entrepreneurship individually, as well as unidimensionally, and includes the mediating role of absorptive capacity and tests several other hypotheses that previously have been ignored. This study, compared to the existing research, contributes to the impact of transformational leadership on corporate entrepreneurship and absorptive capacity, especially in Pakistan's business settings.
\end{abstract}

Keywords: transformational leadership; corporate entrepreneurship; absorptive capacity

\section{Introduction}

The concept of leadership is perhaps one that is quite difficult to define due to its dynamic nature. The nexus between leadership and corporate entrepreneurship is an interesting relationship worthy of investigation due to leadership's undeniable importance to promote corporate entrepreneurship. The dynamic environment, which necessitates the role of corporate entrepreneurship, has led to new strategic imperatives that aim to rethink leadership (Morrisette and Oberman 2013); notably, transformational leadership has been shown to enhance entrepreneurial activities (Ling et al. 2008; Yang 2008), especially where SMEs are an impetus to the future and the sustainability of big firms (Hamburg et al. 2013). As postulated, leadership is one of the key factors behind the successes and failures of SMEs (Quan 2015). Transformational leadership adopts an effective combination of 
holistic and individualistic approaches to meet the collective goals and ambitions of a group, as well as to appraise the follower's motivation (Boberg and Bourgeois 2016; Cheng and Sheu 2017; Muralidharan and Pathak 2018). Moreover, transformational leadership is identified by its ability to bring about significant changes in the organization's strategy, vision, attitude, and culture while advancing creativity and innovation in products, services, and technologies (Cheung and Wong 2011; Chen 2017; Choi et al. 2016). In the current scenario of economic transformation in South Asia, particularly in the China-Pak Economic Corridor (CPEC) context, it is vital for local businesses to utilize their resources (knowledge) in a way that could result in success and sustainable economic growth, stemming from innovation and business venturing. It highlights the importance of such a leadership style that firms should demonstrate to ensure the acquisition and utilization of external knowledge to fulfill the changing needs of the firms. Given that SMEs are the major constituent of this business and economic shift in Pakistan, this study tries to explore the extent to which transformational leadership could serve as a means to corporate entrepreneurship through effective acquisition and utilization of knowledge i.e., absorptive capacity. Furthermore, this study attempts to confirm whether transformational leadership can be a useful tool for corporate entrepreneurship in the current scenario. Therefore, it is important to know about the nexus of transformational leadership and corporate entrepreneurship, including the mediating role of absorptive capacity. Parallel to this, with the noticeable absence of several elements of corporate entrepreneurship either individually or from a unidimensional perspective, this research aims to incorporate developing countries like Pakistan. Though the role of transformational leadership for the survival of businesses through corporate entrepreneurship is well accepted, the literature in this domain is dispersed. For example, several studies (e.g., Eyal and Kark 2004; Yang 2008; Roslan 2010; Öncer 2013; Bakar and Mahmood 2014) develop frameworks on the relationship between transformational leadership and corporate entrepreneurship; however, these studies are limited from three aspects. First, they consider only one or two dimensions of entrepreneurship; secondly, they consider the overall effect and ignore the individual dimensions and vice versa; and finally, they ignore the mediating role of absorptive capacity. The elements of corporate entrepreneurship used in this study are innovation, proactivity, risks-taking, new business venturing, and self-renewal.

This study aims to analyze the role of transformational leadership in affecting corporate entrepreneurship and integrate the dispersed scholarly work on transformational leadership, absorptive capacity, and corporate entrepreneurship under one framework. The paper utilizes the literature on the relationship between transformational leadership and corporate entrepreneurship in a novel way that fills the gap of investigating more dimensions of entrepreneurship individually and unidimensionally; it includes the mediating role of absorptive capacity and tests a number of previously ignored hypotheses. In due course, the present study integrates the dispersed scholastic work on transformational leadership, absorptive capacity, and corporate entrepreneurship into one framework. Further, this study, compared to the existing research, contributes to the impact of transformational leadership on corporate entrepreneurship and absorptive capacity, especially in the Pakistani business settings. This paper is organized as follows. Section 2 discusses the literature review, Section 3 describes the methodology, results are in Section 4, discussions in Section 5, and, finally, there is the conclusion section.

\section{Literature Review}

\subsection{Transformational Leadership and Corporate Entrepreneurship}

\subsubsection{Transformational Leadership}

Bass (1985) extended the work of Burns (1978) and introduced transformational leadership theory. Transformational leadership influences individuals (employees/followers) to attain organizational goals (Hill et al. 2012). Transformational leadership has five elements: idealized influence (behavior), idealized influence (attributed), inspirational motivation, intellectual stimulation, and individual 
consideration. Idealized influence (behavior) can be defined as transformational leaders who display behaviors that enable them to be role models for their followers. Furthermore, these leaders ought to show sincerity and respect, and to infuse passion and self-importance (Bass 1985). Idealized influence (attributed) defines the sense of loyalty, admiration, trust, and respect that followers attribute to these leaders (Puffer and McCarthy 2008). Inspirational motivation refers to the fact that transformational leaders set high expectations on employees and employ imagery and signs to emphasize struggle and communicate the significance of organizational goals (Hoffman et al. 2011). Intellectual stimulation relates to the aptitude of leaders for the development of an environment that is suitable for creativity and innovation, including the empowerment of followers or employees to solve difficult issues. Finally, individualized consideration states that leaders pay attention to the needs and requirements of individual followers or employees and assist them with their self-actualization and growth. This study employed all elements to measure transformational leadership (Eyal and Kark 2004; Yang 2008).

\subsubsection{Corporate Entrepreneurship}

The concept of corporate entrepreneurship refers to entrepreneurial activities carried out within existing firms (Javalgi et al. 2014). These entrepreneurial activities involve innovation, new business venturing, self-renewal, proactivity, and risk-taking (Schmelter et al. 2010). Innovation refers to bringing newness or improving existing products, developing novel products, and the development of new production process. Its focus is on activities or ideas that may indicate changing existing patterns. New business venturing is defined as the creation or establishment of new business by transforming firms' products, i.e., goods and services or creating new market (Kuratko and Audretsch 2013; Ramos-González et al. 2017). Self-renewal refers to firms' transformation by redefining the main objectives in which they were formed. This also refers to the consequences of strategic and radical transformations, including redefining the idea of business, restructuring, and launching system-wide transformations for newness. Self-renewal is an entrepreneurial effort that brings substantial changes in firms' business, corporate strategy, and in hierarchy as well. These changes transform the existing connections in the firm with its external environment. Proactivity is defined as the adoption of proactive approach relative to competitors. A proactive firm is one that takes initiatives to avail opportunities and tries to be the leading competitor instead of a follower. Entrepreneurial firms are trendsetters, not the followers of trends (Miller 1983). The core of proactivity is constant exploration of opportunities with possible outcomes to shift the trends (Venkatraman 1989) and continuous implementation of creative ideas in firms. Risk-taking refers to the readiness of a firm to follow opportunities in which chances are equal to bear losses or substantial fluctuations in performance. Morris and Kuratko (2002) contended that entrepreneurship is not involved in irresponsible and thoughtless decision making. An entrepreneur's involvement in different trials, emerging markets, and experiments will make him more capable in decision-making. Moreover, this expertise comes after some failures, which then lead towards success for a long period of time. Firms that do not innovate probably experience greater risks of not recognizing technological and market changes that are exploited by rivals.

Given the factors of corporate entrepreneurship, ample literature is available on the antecedents that foster it, like leaders (Zahra 1996). Transformational leadership has been recognized by several scholars as one of the significant antecedents for promoting employees' corporate entrepreneurship (Ceptureanu et al. 2017; Chang et al. 2017). Because it involves being passionate about innovation and converting firms' turbulent business environment into business opportunity (Avolio et al. 2004; Howell and Higgins 1990), transformational leadership is thought to encourage their employees to frequently adapt and expect environmental transformation through entrepreneurial activities (Su and Baird 2017; Waldman et al. 2004). Transformational leaders establish new businesses by cultivating markets for novel products (Zahra 1993a). Also, these leaders encourage their employees to think unconventionally and nurture novel notions by involving employees in business venturing (Howell and Higgins 1990; Jung et al. 2003). Transformational leaders enhance their intrinsic motivation to develop innovation potential and venturing tendency, thus increasing firms' aptitude for corporate 
entrepreneurship. These leaders promote entrepreneurial activities by encouraging their employees' inspiration to get engaged in developing novel ideas (Chen et al. 2014; Audenaert et al. 2017). Notably, these leaders assist employees to develop self-efficacy and confidence in striving for innovative work and to perform beyond hopes (Jung et al. 2008). This confidence and motivation engages employees in innovative thinking, new working patterns, and identifying new market opportunities, which are the fundamentals of corporate entrepreneurship. Therefore, transformational leadership is expected to have a positive connection with corporate entrepreneurship in the context of Pakistani SMEs:

H1: transformational leadership has a positive influence on corporate entrepreneurship.

\subsubsection{Transformational Leadership and Innovation}

According to Woodman, Sawyer, and Griffin (Woodman et al. 1993), innovation is the production of useful, valuable, and novel product and/or services. As a result, innovation is the propensity of firms to establish novel or enhanced services/products, as well as their success in delivering these services/products to the market. This perspective is consistent with Damanpour (1991) concept of innovation of product, i.e., bringing novel products/services to the marketplace (OECD 2004).

Transformational leaders foster innovation within firms and increase the propensity of firms to innovate. Leaders' inspirational motivation and intellectual stimulation play a vital role in bringing innovation to firms (Elkins and Keller 2003; Nardelli 2017). According to Howell and Higgins (1990), transformational leaders encourage creative thoughts within their firms; this performance reveals the winning function of transformational leaders. These leaders have a clear vision that stimulates their followers; they harness their enthusiasm to do more than is expected and to increase innovative perspectives in their job. According to Mumford et al. (2002), the consequential sharp stage of stimulation is likely to increase innovation of firms. Numerous examples of experimental research support this positive effect of leaders on innovation (Keller 1992; Shen et al. 2017; Waldman and Atwater 1994). These studies investigate the association between transformational leadership and innovation generally in research and development (R\&D) divisions. A research of thirty-two Taiwanese firms explored that transformational leadership is positively linked with firm innovation, as calculated by research and development expenditures with many patents over the last three years (Jung et al. 2003; Warland and Mayer 2017). Transformational leadership can also have a positive effect on the marketplace victory of innovations. Leaders who express a powerful vision of innovation and show an understanding of force, as well as self-assurance, will strive for marketplace victory of innovation (Jung et al. 2003). Foremost, professional workers may need more than conventional leader performance, particularly in research and development settings in which quality is the major criteria of performance, but not quantity (Keller 1992). Consequently, this research is to analyze if it is a reality or a myth that transformational leadership promotes innovation of firms. Therefore,

H1a: transformational leadership has a positive influence on innovation.

\subsubsection{Transformational Leadership and New Business Venturing}

New business venturing is the second vital dimension of corporate entrepreneurship. Transformational leadership also influences this dimension. Covin and Slevin (2002) and Gupta, MacMillan, and Surie (Gupta et al. 2004) argue that transformational leadership is necessary for top management to move successfully towards new business venturing. Ensley, Hmieleski, and Pearce (Ensley et al. 2006) found that transformational leadership positively affects the performance of new venture under the conditions of a dynamic environment. Although theoretical exposition supports that transformational leadership affects positively new business venturing directly or indirectly through absorptive capacity, the researcher did not find any empirical literature to support the afore-mentioned conception directly. So, this study is first of its kind to draw and test the following hypotheses:

H1b: Transformational has a positive influence on new business venturing. 


\subsubsection{Transformational Leadership and Self-Renewal}

The third dimension of corporate entrepreneurship is self-renewal, which is also influenced by transformational leadership. Theoretical description supports the association between transformational leadership and self-renewal directly and indirectly through absorptive capacity. Transformational leaders, using inspirational motivation, demonstrate particular behaviors of expressing a shared vision, inspiring and stimulating the followers to achieve the targeted objectives. In response, as stated by Morrisette and Oberman (2013), these leaders achieve acceptance of employees about the transformed values and beliefs (vision and mission) of firms, which results in self-renewal of firms. Moreover, transformational leaders acquire knowledge from outside the firm using external sources. They also get external information from their concerned employees through individualized consideration. This external knowledge also helps transformational leaders to promote self-renewal. Therefore, keeping in view above discussion, this study draws and tests the following hypotheses:

H1c: Transformational has a positive influence on self-renewal.

\subsubsection{Transformational Leadership and Proactivity}

Proactivity is the fourth dimension of corporate entrepreneurship. Transformational leaders are proactive; they have the propensity to form the environment instead of reacting or following it passively (Covin and Slevin 1991), and they proactively lead the firms towards the achievement of strategic goals and objectives (Judge and Bono 2000; Lopez-Cabrales et al. 2017). Eyal and Kark (2004) propose that transformational leadership has a positive and significant link with proactivity. Yang (2008) has also found a positive association between transformational leadership and proactivity. Williams, Parker, and Turner (Williams et al. 2010) also examined the same and found positive relationship between transformational leadership and proactivity. Although the mediation of absorptive capacity between transformational leadership and proactivity is supported by theoretical exposition, it lacks empirical support. Considering the theoretical exposition, empirical evidence, and gaps, this study hypothesizes that

H1d: Transformational leadership has a positive influence on proactivity.

\subsubsection{Transformational Leadership and Risk-Taking}

The last dimension of corporate entrepreneurship is risk-taking. A number of scholars argue that transformational leaders enhance risk-taking propensity of a firm. Morrisette and Oberman (2013) argue that transformational leaders provide followers with a secure environment to take risks. Significant empirical literature also claims that transformational leadership enhances the risk-taking ability of a firm. For instance, Yang (2008) found a positive association of transformational leadership with risk taking. Consistent with this, Öncer (2013) also found a positive effect of transformational leadership on risk-taking. Although the mediation of absorptive capacity between transformational leadership and risk taking is supported by theoretical exposition; however, it lacks empirical evidences. Keeping in view the above discussion, this study draws following hypothesis:

H1e: Transformational leadership has a positive influence on risk-taking.

\subsection{Transformational Leadership and Absorptive Capacity}

Absorptive capacity refers to the aptitude of a firm to realize the worth of new knowledge and utilize it for commercial purposes (Cohen and Levinthal 1990). The knowledge-based theory proposes that absorptive capacity can considerably enhance the capacity of a firm to identify and discover novel opportunities by developing new abilities and decreasing cognitive inflexibility among top management (Zahra et al. 2009; Espejo and Dominici 2017). 
Transformational leaders, through intellectual stimulation, stimulate employees to rethink their working patterns and come up with novel working methods (Podsakoff et al. 1990), as well as promote new ways to blend novel insights with available knowledge, as needed in the knowledge transformation step (Zahra and George 2002). These leaders, therefore, enhance novel and creative thinking and produce a positive climate for change (Vera and Crossan 2004). This positive approach towards innovation is additionally underpinned by expressing the vision that motivates employees (Sosik et al. 1998). Moreover, leaders' behavior sets high performance expectations by constantly requiring the best of the employees (MacKenzie et al. 2001), helping the subordinates' effort to continuously search for novel information. Consistent with the theory of strategic leadership (Hernandez et al. 2011), transformational leaders' behavior has been demonstrated to foster recognition, attainment, and examination of outside knowledge (Li et al. 2014). Furthermore, transformational leaders portray a clear picture of future through vision articulation and focus on significance of knowledge transformation and exploitation. Using knowledge exploitation, it is the task of employees to implement knowledge commercially that is in line with the vision of the leader. Absorptive capacity is expected and also found (Flatten et al. 2015) to be positively affected by transformational leadership.

H2: Absorptive capacity has a positive influence on transformational leadership.

\subsection{Absorptive Capacity and Corporate Entrepreneurship}

Cohen and Levinthal (1990) contended that the major reason why few firms are competent to value, sense, and apply new knowledge with lower struggles and costs than other firms is because they have already spent efforts and money on cultivating their absorptive capacity. Teng (2007) argued that such aptitude lessens the knowledge transfer hurdles among firms such as embeddedness and tacitness. Firms with a greater level of absorptive capacity can sense outside knowledge, blend it with their current knowledge, and utilize it for commercial purposes (Zahra and George 2002). Likewise, the major role of absorptive capacity is assisting knowledge transfer, which allows firms to bridge the knowledge gaps they face while pursuing corporate entrepreneurship (Bojica and Fuentes 2012; Teng 2007). By blending internal and external knowledge, firms can attain novel understandings that assist them to identify diverse opportunities for corporate entrepreneurship (Zahra et al. 2009). Absorptive capacity enables companies to sort out something dissimilar, which is contrary to the idea that by doing this, they allow companies to become better than before (Lane et al. 2006). Therefore, it is expected that absorptive capacity imparts outside firm knowledge regarding firms' procedures of value creation, bridging knowledge needs and producing novel knowledge that in turn fosters corporate entrepreneurship. Hence, we propose:

H3: Absorptive capacity has a positive influence on corporate entrepreneurship

\subsection{Mediating Role of Absorptive Capacity}

On the basis of above argumentation, transformational leadership is suggested to be a strategic antecedent that affects knowledge absorption (Camps and Rodríguez 2011; Nemanich and Vera 2009) for example, absorptive capacity (Flatten et al. 2015). Consistent with this, Flatten et al. (2015) advocated that transformational leaders promote absorptive capacity using different methods, especially by articulating a vision that focuses on the significance of knowledge transformation and exploitation, and by presenting a suitable model that demonstrates how vital it is to develop firms' knowledge base. This aptitude to absorb knowledge, enhanced by transformational leadership, allows firms to identify new knowledge, mix it with their existing knowledge, and then employ such knowledge in firms' processes of value creation, overcoming knowledge gaps and producing novel knowledge that in turn promotes corporate entrepreneurship. Firms that have external knowledge can recognize where to find novel opportunities and how to take advantage of them (Cohen and Levinthal 1990); however, although they eager to avail themselves of the benefits of these opportunities, knowledge 
resources are likely to be insignificant (Pérez-Luño et al. 2011). This might explain why few firms can obtain and utilize outside gained information but are not able to use it positively promoting corporate entrepreneurship. Furthermore, absorptive capacity might involve difficult issues and elevate firms' aptitudes to identify and respond to novel opportunities (Tsai 2001). In addition to these contentions, the demonstration of transformational leadership behavior might be augmented on the basis of firms' competencies to obtain outside information. This is particularly true for the higher turbulence of dynamic environment when it is hard to sense what competitors are planning, to obtain their information, and to implement it in novel products and procedures (Pérez-Luño et al. 2011). Belderbos, Gilsing, and Suzuki (Belderbos et al. 2016) also discovered that absorptive capacity has a more indirect than direct effect on the dimensions of corporate entrepreneurship. Hence, the exhibition of transformational leadership behavior is more useful just with the existance of absorptive capacity mechanism to promote corporate entrepreneurship. Empirical studies addressing the mediating role of absorptive capacity for transformational leadership and corporate entrepreneurship nexus are scarce; however, above discussion supports the likelihood of absorptive capacity' mediation in this relationship. Therefore, we posit:

H4: Absorptive capacity mediates the relationship between transformational leadership and corporate entrepreneurship.

\section{Methodology}

\subsection{Population and Sample}

Within the range of established firms, this study considers SMEs because of two major reasons. First, firms having less than 500 employees comprise approximately $90 \%$ of all employer firms in Pakistan; consequently, they are a primary source of innovation and economic growth. Second, researchers have overlooked this fragment of firms to date. It is expected that corporate entrepreneurship and its antecedents would be more practical and straightforward in SMEs as compared to large-scale organizations. Hayton (2003) emphasized that large-scale organizations must develop "complex, codified entrepreneurial cultures, and ambidextrous structure" to innovate. Thus, SMEs serve as an appropriate targeted population to study corporate entrepreneurship (Cucculelli and Cristina 2015; Hughes and Michael 2017)

Given that this study aims to explore the effect of transformational leadership on entrepreneurship among SME firms, a total of 950 SME firms were selected using cluster sampling technique from six manufacturing industries (textile, leather/footwear, sports, food \& beverages, wood \& furniture) for data collection because of their significant contribution to GDP and employment. Total 950 questionnaires-one questionnaire per firm-(Urdu translation was parallel to English) were distributed and representative (Owner/CEO/Manager) of each firm was requested to fill in the questionnaire. Table 1 presents the sample distribution details. Unit of analysis is SME firm. However, the firm size ranged from 37 to 203 with an average size of 163.67 employees. A total of 433 firms (46\%) responded, out of which 400 responses were used for further analysis. A total of 433 responses $(46 \%)$ were finally collected, and only 400 responses were used for further analysis. Out of four hundred firms' representatives, two hundred and ten (52.5\%) were females and one hundred and ninety $(47.5 \%)$ were male respondents. The age of respondents ranged from 24 to 57 years (mean $=32.4$ ). Moreover, two hundred and sixty-seven $(66.75 \%)$ were CEOs, eighty-eight $(22 \%)$ were owners, and forty-five $(11.25 \%)$ were other managers. Eighty $(20 \%)$ respondents had job experience up to five (5) years, seventy-six (19\%) reported their experience between 6 to 10 years, one hundred and fifty-eight $(39.5 \%)$ participants reported an experience between 11 to 15 years, and sixty-five $(16.25 \%)$ respondents had job experience above fifteen (15) years. However, twenty-one (5.25\%) respondents did not report their job experience. Moreover, fifty-one $(12.75 \%)$ respondents had their education at under graduation level, two hundred and ninety-one $(72.75 \%)$ had education at graduation level, and thirty-six (9\%) 
respondents reported post-graduation as their education level. Hence, twenty-two (5.5\%) respondents did not report their education. Table 2 includes the demographic details of the firms' representatives.

Table 1. Samples Distribution.

\begin{tabular}{ccccc}
\hline No. & Industry & \% & Firms & Firms Responded \\
\hline 1 & Textile & 23 & 224 & 131 \\
2 & Leather/Footwear & 17 & 159 & 74 \\
3 & Sports & 14 & 139 & 102 \\
4 & Food \& Beverages & 21 & 205 & 67 \\
5 & Metal & 11 & 103 & 27 \\
6 & Wood \& Furniture & 14 & 120 & 32 \\
Total & & 100 & 950 & 433(useable-400) \\
\hline
\end{tabular}

Note: \% refers the sectorial contribution to GDP.

Table 2. Representatives' Demographics.

\begin{tabular}{cc}
\hline Demographics & Firms' Representatives \\
\hline Gender: & \\
\hline Male & 190 \\
Female & 210 \\
\hline Age: & \\
\hline Range & $24-57$ \\
Average & 32.4 \\
\hline Management level: & \\
\hline CEOs & 267 \\
Owners & 88 \\
Managers & 45 \\
\hline Job Experience: & \\
\hline$\leq 5$ years & 80 \\
$6-10$ years & 76 \\
11-15 years & 158 \\
$\geq 15$ years & 65 \\
Not reported & 21 \\
\hline Education: & \\
\hline Under graduation & 51 \\
Graduation & 291 \\
Post-graduation & 36 \\
Not reported & 22 \\
\hline &
\end{tabular}

\subsection{Measures}

This study used pre-developed and pre-tested constructs to measure concerned variables. Multifactor Leadership Questionnaire (MLQ Form 5X-short) is adapted to measure the transformational leadership (Bass and Avolio 1995, 2004), which includes 20 items ranging from " $1=$ Not at all" to " $5=$ frequent". Corporate entrepreneurship is measured by combining two different scales, namely Corporate Entrepreneurship scale and ENTERSCALE. Corporate entrepreneurship scale includes innovation, new business venturing, and self-renewal, which is developed and refined by Zahra (1991, 1993a) and Antoncic (2007). Proactivity and risk-taking are measured using ENTERSCALE, which is developed by Khandwalla (1977), and refined by Covin and Slevin (1989), and Knight (1997). Each innovation and new business venturing is measured by five items ranging from " $1=$ Increased Significantly" to " $5=$ Decreased Significantly". Self-renewal is also measured by five items ranging from "1 = Minor Emphasis" to "Major Emphasis". Proactivity is measured by four items; risk-taking is measured by six items, which range from " $1=$ Strongly Disagree" to "Strongly Agree". Absorptive capacity is measured by a 14-item scale that is developed by Zahra and George (2002), further refined 
by Flatten, Engelen, Zahra, and Brettel (Flatten et al. 2011) ranging from " 1 = Strongly Disagree" to "5 = Strongly Agree".

\subsection{Analysis}

First, a preliminary analysis was performed to check the data accuracy, missing values, outliers, normality, and multicollinearity in the data. Secondly, confirmatory factor analysis (CFA) was performed employing AMOS 22.0 to analyze the psychometric properties of the constructs to ensure validity (convergent \& discriminant). Finally, SEM is used to test the conceptual model and hypotheses of the study.

Table 3 presents the mean, standard deviation, correlations, Cronbach $\alpha$, composite reliability (CR), average variance extracted (AVE), and square root of AVE of the constructs. Moreover, factor loadings of the items are also checked, and items with weak factor loadings $(<0.50)$ have been deleted. Factor loadings of the final items are ensured $(>0.50)$ to fulfill the criteria of convergent validity (Bagozzi and Yi 1988). Discriminant validity is measured by comparing each construct's square root of AVE with its parallel correlations (Fornell and Larcker 1981). As depicted in Table 3, the values of the square root of AVEs are greater than corresponding construct's correlations, ensuring the discriminant validity. The values of Cronbach $\alpha$ and CR of all the constructs are acceptable $(>0.70)$. Likewise, the values of AVEs and square root of AVE (in the parenthesis of Table 3) are greater than 0.50 and are, therefore, acceptable (Fornell and Larcker 1981). Furthermore, we have adopted Harman's single-factor test (Podsakoff and Organ 1986) by entering all items together into a factor analysis, and the results of the un-rotated factor solution are examined. If substantial common method variance is present, either a single factor may emerge or one general factor would explain most of the covariance in the independent and criterion variables. In this study, all the items were included in a principal component of factor analysis. The tests indicated that common method variance was not a problem in this study. Durbin-Watson test is employed to ensure the autocorrelation among the variables, since this study uses two-phase modeling, measurement model, and structural model (Hair et al. 2010). Table 3 also includes the goodness-of-fit of each construct (measurement model) with the finalized items. Goodness-of-fit of each construct is measured through the goodness-of-fit index (GFI), comparative-fit-index (CFI), root mean square error of approximation (RMSEA), and normed chi-square $\left(\mathrm{X}^{2} / \mathrm{df}\right)$. The acceptable range for GFI is $\geq 0.90$ for CFI is $\geq 0.90$, for RMSEA is $<0.08$, and for normed chi-square is $1.0 \leq X^{2} / \mathrm{df} \leq 5.0$ (Hair 1998). As shown in Table 3, the values of all the fit indices ensured the fitness of the measurement models with the data.

Table 3. Descriptive Statistics.

\begin{tabular}{|c|c|c|c|c|c|c|c|c|c|}
\hline & Means & SD & 1 & 2 & 3 & 4 & 5 & 6 & 7 \\
\hline 1.TL & 4.1795 & 0.69717 & $(0.712)$ & & & & & & \\
\hline 2.INN & 4.0369 & 0.80649 & $0.350^{* * *}$ & $(0.75)$ & & & & & \\
\hline 3.NBV & 3.9588 & 0.88207 & $0.342^{* * *}$ & $0.347^{* * *}$ & $(0.72)$ & & & & \\
\hline 4.SR & 3.9355 & 0.88832 & $0.286^{* * *}$ & $0.304^{* * *}$ & $0.262^{* * *}$ & $(0.74)$ & & & \\
\hline 5.PRO & 3.6838 & 0.97509 & $0.339^{* * *}$ & $0.175^{* * *}$ & $0.282^{* * *}$ & $0.351^{* * *}$ & $(0.71)$ & & \\
\hline 6.RT & 3.7456 & 0.94066 & $0.360 * * *$ & $0.184^{* * *}$ & $0.252 * * *$ & $0.347^{* * *}$ & $0.445^{* * *}$ & $(0.73)$ & \\
\hline 7.AC & 4.1046 & 0.76039 & $0.361^{* * *}$ & $0.426^{* * *}$ & $0.343 * * *$ & $0.341^{* * *}$ & $0.380 * * *$ & $0.406^{* * *}$ & $(0.72)$ \\
\hline 8.CE & 3.8721 & 0.59509 & $0.506^{* * *}$ & $0.580 * * *$ & $0.641^{* * *}$ & $0.683^{* * *}$ & $0.704^{* * *}$ & $0.690 * * *$ & $0.572 * * *$ \\
\hline AVE & - & - & 0.508 & 0.562 & 0.518 & 0.558 & 0.506 & 0.536 & 0.525 \\
\hline $\mathrm{CR}$ & - & - & 0.912 & 0.773 & 0.81 & 0.863 & 0.802 & 0.821 & 0.885 \\
\hline $\begin{array}{c}\text { Cronbach } \\
\alpha\end{array}$ & - & - & 0.912 & 0.771 & 0.804 & 0.563 & 0.800 & 0.815 & 0.884 \\
\hline GFI & - & - & 0.934 & 0.982 & 0.995 & 0.993 & 0.979 & 0.986 & 0.966 \\
\hline CFI & - & - & 0.949 & 0.994 & 0.998 & 0.997 & 0.993 & 0.995 & 0.977 \\
\hline RMSEA & - & - & 0.085 & 0.055 & 0.033 & 0.038 & 0.066 & 0.057 & 0.071 \\
\hline$X^{2} / \mathrm{df}$ & - & - & 3.884 & 2.194 & 1.433 & 1.574 & 2.715 & 2.291 & 3.014 \\
\hline
\end{tabular}

**** represent level of significance at $0.1 \%$. 


\subsection{Structural Models}

This research employed two structural models to analyze the hypotheses (direct and indirect). In structural model 1 , the direct and indirect (through absorptive capacity) effect of transformational leadership on corporate entrepreneurship is analyzed. However, the direct and indirect influence of transformational leadership on the individual dimensions of corporate entrepreneurship is checked in structural model 2. Before testing the hypotheses, the fitness of the models with the data is tested. The structural model 1 shows good fit with the data on all indices (GFI $=0.941, \mathrm{CFI}=0.964$, RMSEA $\left.=0.037, \mathrm{X}^{2} / \mathrm{df}=2.463\right)$. Similarly, structural model 2 also depicts a good fit with the data $\left(\mathrm{GFI}=0.973, \mathrm{CFI}=0.947, \mathrm{RMSEA}=0.068, \mathrm{X}^{2} / \mathrm{df}=2.673\right)$. Hence, both models have goodness-of-fit with the data on all indices.

Table 4 presents the results of both structural models. These results demonstrate that transformational leadership has a significant direct effect on corporate entrepreneurship and absorptive capacity. Moreover, absorptive capacity significantly mediates the effect of transformational leadership on corporate entrepreneurship. Similarly, transformational leadership has significant direct and indirect (via absorptive capacity) impact on innovation, new business venturing, self-renewal, proactivity, and risks taking. The individual dimensions of corporate entrepreneurship are more influenced by absorptive capacity rather than transformational leadership.

Table 4. Standardized Effects.

\begin{tabular}{ccccc}
\hline Paths & Direct & Indirect & Total & Result \\
\hline Structural Model 1 & & & \\
\hline $\mathrm{TL} \rightarrow \mathrm{CE}$ & $0.423^{* * *}$ & $0.224^{* * *}$ & $0.647^{* * *}$ & Accepted \\
$\mathrm{TL} \rightarrow \mathrm{AC}$ & $0.395^{* * *}$ & - & $0.395^{* * *}$ & Accepted \\
$\mathrm{AC} \rightarrow \mathrm{CE}$ & $0.567^{* * *}$ & - & $0.567^{* * *}$ & Accepted \\
\hline Structural Model 2 & & & \\
\hline $\mathrm{TL} \rightarrow \mathrm{INN}$ & $0.246^{* * *}$ & $0.163^{* * *}$ & $0.410^{* * *}$ & Accepted \\
$\mathrm{TL} \rightarrow \mathrm{NBV}$ & $0.290^{* * *}$ & $0.140^{* * *}$ & $0.402^{* * *}$ & Accepted \\
$\mathrm{TL} \rightarrow \mathrm{SR}$ & $0.214^{* * *}$ & $0.170^{* * *}$ & $0.342^{* * *}$ & Accepted \\
$\mathrm{TL} \rightarrow \mathrm{PRO}$ & $0.253^{* * *}$ & $0.165^{* * *}$ & $0.396^{* * *}$ & Accepted \\
$\mathrm{TL} \rightarrow \mathrm{RT}$ & $0.276^{* * *}$ & $0.192^{* * *}$ & $0.431^{* * *}$ & Accepted \\
$\mathrm{TL} \rightarrow \mathrm{AC}$ & $0.394^{* * *}$ & - & $0.394^{* * *}$ & Accepted \\
$\mathrm{AC} \rightarrow \mathrm{INN}$ & $0.415^{* * *}$ & - & $0.415^{* * *}$ & Accepted \\
$\mathrm{AC} \rightarrow \mathrm{NBV}$ & $0.285^{* * *}$ & - & $0.285^{* * *}$ & Accepted \\
$\mathrm{AC} \rightarrow \mathrm{SR}$ & $0.322^{* * *}$ & - & $0.322^{* * *}$ & Accepted \\
$\mathrm{AC} \rightarrow \mathrm{PRO}$ & $0.362^{* * *}$ & - & $0.362^{* * *}$ & Accepted \\
$\mathrm{AC} \rightarrow \mathrm{RT}$ & $0.393^{* * *}$ & - & $0.393^{* * *}$ & Accepted \\
\hline & $* * *$ represent level of significance at $0.1 \%$. &
\end{tabular}

\section{Discussion}

This study contributes to the literature by analyzing the influence of transformational leadership on the dimensions of corporate entrepreneurship. Findings of the study reveal that transformational leadership has a significant positive influence on corporate entrepreneurship. These results are largely consistent with previous empirical studies. For instance, Ling et al. (2008) found a positive relationship between transformational leadership (CEOs) and corporate entrepreneurship (innovation, venturing, and strategic renewal). Moriano, Molero, Topa, and Mangin (Moriano et al. 2014) also found that there is a positive association between transformational leadership and corporate entrepreneurship (pro-activeness, risk-taking, and innovativeness). The positive significant influence of transformation leadership on innovation (García-Morales et al. 2012; Ryan and Tipu 2013), new business venturing (Ensley et al. 2006), proactivity (Eyal and Kark 2004; Williams et al. 2010), and risk taking (Öncer 2013) has been extensively discussed in the empirical literature. Transformational leaders positively influence employees' creativity by questioning employees established beliefs, assumptions, and standards which 
results in firm-level innovation (Bass and Riggio 2006). Through involving employees in decision making process, the creative notions of individuals are employed by top management for new business venturing and self-renewal. By utilizing inspirational motivation, these leaders express the vision and mission that appeal to the employees. This appealing vision stimulates the proactive approach of employees, which enhances firms' proactivity. Transformational leaders insist that followers take risks to apply their creative ideas and notions; leaders also take risks on the basis of novel solutions or ideas from followers, which in turn increases firms' risk taking ability. This positive nexus exists in collectivist Pakistan, strengthening the contentions by Bass (1985) that transformational leadership is more expected to appear in collectivist settings than in the individualistic contexts of the West, and that collectivists execute well under transformational leadership. Substantial studies stated a stronger positive influence of transformational leadership on individuals' and organizational outcomes of collectivists than individualists (Avolio et al. 2004; Gumusluoglu and Arzu 2009; Chang et al. 2017).

The findings also reveal that absorptive capacity mediates the relationship between transformational leadership and corporate entrepreneurship' dimensions (García-Morales et al. 2012). This finding is a significant contribution to the literature in that it exhibits absorptive capacity as a critical organizational mechanism by which transformational leadership affects corporate entrepreneurship. Transformational leaders elevate absorptive capacity among employees and in the firms by empowering the employees. They impart aptitudes, obligations, expertise, and knowledge to the organizational members, who can employ it to obtain, apply, convert, and adopt a novel practice and develop in-house communication via decreasing hurdles in knowledge sharing; thus, the effectiveness of absorption process enhanced (Cohen and Levinthal 1990). Since absorptive capacity permits exploitation and assimilation of outside knowledge, it enhances the promotion of corporate entrepreneurship (Zahra et al. 2009). Through absorptive capacity, firms engage themselves to develop novel products, processes, and networks pertinent to corporate entrepreneurship activities. This incessant hunt and utilization of novel business opportunities, i.e., corporate entrepreneurship (Hayton and Kelley 2006), impart novel knowledge and resources into firms' processes from numerous outside sources (Zahra et al. 2009). Consequently, by acquiring and exploiting external knowledge and sources, firms organize them to assist corporate entrepreneurship consequences (Bojica and Fuentes 2012). This study also contributes methodologically to the literature by analyzing transformational leadership, absorptive capacity, and corporate entrepreneurship in Pakistan, a developing economy; it demonstrates the validity of these theories, which were established and have been analyzed in Western developed economies.

\section{Implications}

Dess and Picken (2000) emphasized that the business environment of the twenty-first century needs firms to innovate continuously by integrating the knowledge, skills, and creative efforts of its their members. As findings of this study have revealed, transformational leadership is one of the key drivers of such outcomes. Moreover, given that various 'aspects of leadership behavior can be learned or adjusted' (Kirkbride 2006), we can infer that SMEs can nurture entrepreneurial activity by promoting absorptive capacity and fostering transformational leadership. In SMEs where resources are usually scarce (Liao and Welsch 2005), managers/leaders need to be aware that building knowledge-acquisition and absorption capacity helps firms to get involved in continuous learning, thus fostering entrepreneurial activities that help firms to compete for limited resources and influence performance positively. Leaders must cope with the costs resulting from building absorptive capacity and knowledge resources allocation, because absorptive capacity seems to be more valuable for firms that have high levels of knowledge-based resources (Bojica and Fuentes 2012).

To develop absorptive capacity, SME firms are advised to foster transformational leadership, because it not only facilitates to build absorptive capacity but also serves as an important driver of corporate entrepreneurship. To improve transformational leadership skills in management, appropriate education and training of key personnel of SMEs are essential for transformational leadership. Firms should invest to initiate transformational leadership training programs for their managers 
and also focus on hiring the managers that have transformational style of leadership if their aim is to promote corporate entrepreneurship. Leaders are important stakeholders who can enable their employees to thrive and innovate (Choi et al. 2016). It points to the fact that rapidly changing business environment requires the transformational style of leadership that could transform organizations where command and control leadership style is slowly diminishing, especially in SMEs settings. Transformational leaders, through intellectual stimulation and absorptive capacity, can further force employees to question systems, processes, and assumptions, thereby coming up with innovation and creative ideas to address the challenges they face rather just adopting a directive approach to leadership. Thus, transformational leadership approach encourages corporate entrepreneurship through self-renewal, proactivity, innovation, new business venturing, and risk-taking where all these could be managed with the process of change.

\section{Limitations and Future Research}

This study has some limitations. First, it was conducted in the limited manufacturing sectors (textile, leather/footwear, sports, food and beverages, metal, and wood and furniture) in Pakistan. Therefore, the results of the study and the importance of leadership styles can be further investigated in other sectors. Secondly, this is a cross-sectional study that has limitations compared to a longitudinal study. Thirdly, this study hypothesized only three leadership styles to analyze the promotion of corporate entrepreneurship in SMEs manufacturing sector; other leadership styles and factors (e.g., financial strength, market reputation, and physical assets) have been ignored. Finally, this study also does not consider the financial barriers that SMEs face generally. It is possible that SMEs have transformational leaders but they do not perform well due to adverse financial circumstances.

This study recommends that future studies should also include the data from other manufacturing sectors, especially surgical equipment, chemical, carpet, and electronic industries. This study also suggests that the scope can be narrowed to individual industries to develop industry-based policy. Moreover, other variables such as firms' goodwill, physical assets, and financial strength can be added to analyze whether transformational leadership continues to influence corporate entrepreneurship. Though this study has found positive direct and indirect (through absorptive capacity) links between transformational leadership and innovation, future studies can examine the effects of each dimension of transformational leadership on innovation. Similarly, further studies can also assess the mediation of each dimension of absorptive capacity.

\section{Conclusions}

Findings suggest that transformational leadership positively affects corporate entrepreneurship and its dimensions, both directly and indirectly through absorptive capacity. This model provides guidelines for top management, decision makers, and policy makers to become successful entrepreneurs and innovators. Employing this model, organizational stakeholders can realize the dimensions of corporate entrepreneurship, which needs to be improved to ensure the survival of SMEs. SMEs owners or top management ought to recruit managers and directors while paying special attention to their transformational leadership capability. Thus, research and development (R\&D) capacity is highly encouraged to develop and promote entrepreneurial culture (corporate entrepreneurship). Nevertheless, SMEs in Pakistan face survival issues despite the support of government (technical assistance, law and order, subsidized loans, conducive environment, etc.). Top managers of SMEs can reduce the failure rate through the leadership approach rather than relying on government. This study emphasizes transformational leadership and the absorptive capacity to promote corporate entrepreneurship, which could decrease SMEs' failure rate. The results depict a significant effect of transformational leadership and the absorptive capacity of corporate entrepreneurship.

Government agencies are advised to enhance transformational leadership skills by focusing on training and education of SMEs top management. Promotion of top management training is a beneficial measure in the short-term, while the government may focus to improve corporate entrepreneurship 
through appropriate professional education and training in the long term. This study is conducted in limited manufacturing sectors (textile, leather/footwear, sports, food and beverages, metal, and wood and furniture) in one major province of Pakistan. Thus, the results of the study and the importance of transformational leadership can be further improved by including other sectors such as surgical equipment, chemical, carpet, and electronic industries. Likewise, this is a cross-sectional study with its limitations; therefore, a longitudinal analysis may be helpful. Moreover, this study hypothesized only one leadership style to analyze the promotion of corporate entrepreneurship in SMEs manufacturing sector; other leadership styles and factors (e.g., financial strength, market reputation, and physical assets) can be further included in future research. Similarly, this study also does not consider the financial barriers that SMEs generally face.

Author Contributions: Both authors contributed equally to this work.

Conflicts of Interest: The authors declare no conflicts of interest.

\section{References}

Antoncic, Bostjan. 2007. Intrapreneurship: A comparative structural equation modeling study. Industrial Management \& Data Systems 107: 309-25.

Audenaert, Mieke, Alex Vanderstraeten, and Dirk Buyens. 2017. When innovation requirements empower individual innovation: the role of job complexity. Personnel Review 46: 608-23. [CrossRef]

Avolio, Bruce, Weichun Zhu, William Koh, and Puja Bhatia. 2004. Transformational leadership and organizational commitment: Mediating role of psychological empowerment and moderating role of structural distance. Journal of Organizational Behavior 25: 951-68. [CrossRef]

Bagozzi, Richard P., and Youjae Yi. 1988. On The Evaluation of Structural Equation Models. Journal of the Academy of Marketing Science 16: 74-94. [CrossRef]

Bakar, Muhammad Shukri, and Rosli Mahmood. 2014. Linking Transformational Leadership and Corporate Entrepreneurship to Performance in the Public Higher Education Institutions in Malaysia. Advances in Management and Applied Economics 4: 109-22.

Bass, Bernard M. 1985. Leadership and Performance Beyond Expectations. New York: Free Press, New York: Collier Macmillan.

Bass, Bernard M., and Bruce J. Avolio. 1995. Multifactor Leadership Questionnaire: Manual Leader Form, Rater and Scoring Key for MLQ (Form 5x-Short). Redwood City: Mind Garden Inc.

Bass, Bernard M., and Bruce J. Avolio. 2004. Manual for the Multifactor Leadership Questionnaire (MLQ-Form 5x). Redwood City: Mind Garden Inc.

Bass, Bernard M., and Ronald E. Riggio. 2006. Transformational Leadership, 2nd ed. Mahwah: Lawrence Erlbaum Associates, Inc.

Belderbos, René, Victor A. Gilsing, and Shinya Suzuki. 2016. Direct and mediated ties to universities:"Scientific" absorptive capacity and innovation performance of pharmaceutical firms. Strategic Organization 14: 32-52. [CrossRef]

Boberg, John Eric, and Steven J. Bourgeois. 2016. The effects of integrated transformational leadership on achievement. Journal of Educational Administration 54: 357-74. [CrossRef]

Bojica, Ana Maria, and Maria del Mar Fuentes Fuentes. 2012. Knowledge acquisition and corporate entrepreneurship: Insights from Spanish SMEs in the ICT sector. Journal of World Business 47: 397-408. [CrossRef]

Burns, James M. 1978. Leadership, 1st ed. New York: Harper \& Row.

Camps, Joaquín, and Hannia Rodríguez. 2011. Transformational leadership, learning, and employability: Effects on performance among faculty members. Personnel Review 40: 423-42. [CrossRef]

Ceptureanu, Eduard Gabriel, Sebastian Ion Ceptureanu, and Doina I. Popescu. 2017. Relationship between Entropy, Corporate Entrepreneurship and Organizational Capabilities in Romanian Medium Sized Enterprises. Entropy 19: 412. [CrossRef]

Chang, Yi-Ying, Che-Yuan Chang, and Chung-Wen Chen. 2017. Transformational leadership and corporate entrepreneurship: Cross-level mediation moderation evidence. Leadership E Organization Development Journal 38: 812-33. 
Chen, Chun-Liang. 2017. Service providers' sustainable service innovation: Service-dominant logic. The Service Industries Journal 37: 628-56. [CrossRef]

Chen, Yang, Guiyao Tang, Jiafei Jin, Qinghong Xie, and Ji Li. 2014. CEOs' transformational leadership and product innovation performance: The roles of corporate entrepreneurship and technology orientation. Journal of Product Innovation Management 31: 2-17. [CrossRef]

Cheng, Colin CJ, and Chwen Sheu. 2017. When are strategic orientations beneficial for collaborative service innovation? The Service Industries Journal 37: 466-93. [CrossRef]

Cheung, Millissa FY, and Chi-Sum Wong. 2011. Transformational leadership, leader support, and employee creativity. Leadership \& Organization Development Journal 32: 656-72.

Choi, Suk Bong, Kihwan Kim, SM Ebrahim Ullah, and Seung-Wan Kang. 2016. How transformational leadership facilitates innovative behavior of Korean workers: Examining mediating and moderating processes. Personnel Review 45: 459-79. [CrossRef]

Cohen, Wesley M., and Daniel A. Levinthal. 1990. Absorptive Capacity: A New Perspective on Learning and Innovation. Administrative Science Quarterly 35: 128-52. [CrossRef]

Covin, Jeffrey G., and Dennis P. Slevin. 1989. Strategic Management of Small Firms in Hostile and Benign Environments. Strategic Management Journal 10: 75-87. [CrossRef]

Covin, Jeffrey G., and Dennis P. Slevin. 1991. A Conceptual Model of Entrepreneurship as Firm Behavior. Entrepreneurship Theory and Practice 3: 7-24. [CrossRef]

Covin, Jeffrey G., and Dennis P. Slevin. 2002. The Entrepreneurial Imperatives of Strategic Leadership. In Strategic Entrepreneurship: Creating a New Mindset. Edited by M. A. Hitt, R. D. Ireland, S. M. Camp and D. L. Sexton. Oxford: Blackwell Publishers, pp. 309-27.

Cucculelli, Marco, and Bettinelli Cristina. 2015. Business models, intangibles and firm performance: evidence on corporate entrepreneurship from Italian manufacturing SMEs. Small Business Economics 45: 329-50. [CrossRef]

Damanpour, Fariborz. 1991. Organizational innovation: A meta-analysis of effects of determinants and moderators. Academy of Management Journal 34: 555-90. [CrossRef]

Dess, Gregory, and Joseph Picken. 2000. Changing roles: Leadership in the 21st century. Organizational Dynamics 28: 18-34. [CrossRef]

Elkins, Teri, and Robert T. Keller. 2003. Leadership in research and development organizations: A literature review and conceptual framework. The Leadership Quarterly 14: 587-606. [CrossRef]

Ensley, Michael D., Keith M. Hmieleski, and Craig L. Pearce. 2006. The Importance of Vertical and Shared Leadership within New Venture Top Management Teams: Implications for the Performance of Startups. The Leadership Quarterly 17: 217-31. [CrossRef]

Espejo, Raul, and Gandolfo Dominici. 2017. Cybernetics of value cocreation for product development. Systems Research and Behavioral Science 34: 24-40. [CrossRef]

Eyal, Ori, and Ronit Kark. 2004. How Do Transformational Leaders Transform Organizations? A Study of the Relationship Between Leadership and Entrepreneurship. Leadership and Policy in Schools 3: 211-35. [CrossRef]

Flatten, Tessa C., Andreas Engelen, Shaker A. Zahra, and Malte Brettel. 2011. A Measure of Absorptive Capacity: Scale Development and Validation. European Management Journal 29: 98-116. [CrossRef]

Flatten, Tessa, Daniel Adams, and Malte Brettel. 2015. Fostering absorptive capacity through leadership: A cross-cultural analysis. Journal of World Business 50: 519-34. [CrossRef]

Fornell, Claes, and David F. Larcker. 1981. Evaluating Structural Equation Models with Unobservable Variables and Measurement Error. Journal of Marketing Research 18: 39-50. [CrossRef]

García-Morales, Víctor Jesús, María Magdalena Jiménez-Barrionuevo, and Leopoldo Gutiérrez-Gutiérrez. 2012. Transformational Leadership Influence on Organizational Performance Through Organizational Learning and Innovation. Journal of Business Research 65: 1040-50. [CrossRef]

Gumusluoglu, Lale, and Ilsev Arzu. 2009. Transformational leadership, creativity, and organizational innovation. Journal of Business Research 62: 461-73. [CrossRef]

Gupta, Vipin, Ian C. MacMillan, and Gita Surie. 2004. Entrepreneurial Leadership: Developing and Measuring a Cross-Cultural Construct. Journal of Business Venturing 19: 241-60. [CrossRef]

Hair, Joseph F. 1998. Multivariate Data Analysis. Upper Saddle River: Pearson Prentice Hall.

Hair, Joseph F., William C. Black, and Barry J. Babin. 2010. Multivariate Data Analysis: A Global Perspective, 7th ed. Englewood Cliffs: Prentice Hall. 
Hamburg, Ileana, Emma O. Brien, and Steffi Engert. 2013. Engaging SMEs in Cooperation and New Forms of Learning. Computer and Information Science 7: 1-9. [CrossRef]

Hayton, James. 2003. Strategic human capital management in SMEs: An empirical study of entrepreneurial performance. Human Resource Management 42: 375-91. [CrossRef]

Hayton, James, and Donna Kelley. 2006. A competency-based framework for promoting corporate entrepreneurship. Human Resource Management 45: 407-27. [CrossRef]

Hernandez, Morela, Marion B. Eberly, Bruce J. Avolio, and Michael D. Johnson. 2011. The loci and mechanisms of leadership: Exploring a more comprehensive view of leadership theory. The Leadership Quarterly 22: 1165-85. [CrossRef]

Hill, N. Sharon, Myeong-Gu Seo, Jae Hyeung Kang, and M. Susan Taylor. 2012. Building employee commitment to change across organizational levels: The influence of hierarchical distance and direct managers' transformational leadership. Organization Science 23: 758-77. [CrossRef]

Hoffman, Brian J., Bethany H. Bynum, Ronald F. Piccolo, and Ashley W. Sutton. 2011. Person-organization value congruence: How transformational leaders influence work group effectiveness. Academy of Management Journal 54: 779-96. [CrossRef]

Howell, Jane M., and Christopher A. Higgins. 1990. Champions of Technological Innovation. Administrative Science Quarterly 35: 317-41. [CrossRef]

Hughes, Mathew, and Mustafa Michael. 2017. Antecedents of corporate entrepreneurship in SMEs: Evidence from an emerging economy. Journal of Small Business Management 55: 115-40. [CrossRef]

Javalgi, Rajshekhar G., Kenneth D. Hall, and S. Tamer Cavusgil. 2014. Corporate entrepreneurship, customer-oriented selling, absorptive capacity, and international sales performance in the international B2B setting: Conceptual framework and research propositions. International Business Review 23: 1193-202. [CrossRef]

Judge, Timothy A., and Joyce E. Bono. 2000. Five-factor Model of Personality and Transformational Leadership. Journal of Applied Psychology 85: 751. [CrossRef] [PubMed]

Jung, Dong I., Chee Chow, and Anne Wu. 2003. The Role of Transformational Leadership in Enhancing Organizational Innovation: Hypotheses and Some Preliminary Findings. The Leadership Quarterly 14: 525-44. [CrossRef]

Jung, Dongil Don, Anne Wu, and Chee W. Chow. 2008. Towards understanding the direct and indirect effects of CEOs' transformational leadership on firm innovation. The Leadership Quarterly 19: 582-94. [CrossRef]

Keller, RobertT. 1992. Transformational leadership and the performance of research and development project groups. Journal of Management 18: 489-501. [CrossRef]

Khandwalla, Pradip N. 1977. The Design of Organizations, 1st ed. New York: Harcourt Brace Jovanovich.

Kirkbride, Paul. 2006. Developing transformational leaders: the full range leadership model in action. Industrial and Commercial Training 38: 23-32. [CrossRef]

Knight, Gary A. 1997. Cross-cultural Reliability and Validity of a Scale to Measure Firm Entrepreneurial Orientation. Journal of Business Venturing 12: 213-25. [CrossRef]

Kuratko, Donald F., and David B. Audretsch. 2013. Clarifying the domains of corporate entrepreneurship. International Entrepreneurship and Management Journal 9: 323-35. [CrossRef]

Lane, Peter J., Balaji R. Koka, and Seemantini Pathak. 2006. The reification of absorptive capacity: A critical review and rejuvenation of the construct. Academy of Management Review 31: 833-63. [CrossRef]

Li, Guiquan, Yufan Shang, Haixin Liu, and Youmin Xi. 2014. Differentiated transformational leadership and knowledge sharing: A cross-level investigation. European Management Journal 32: 554-63. [CrossRef]

Ling, Yan, Zeki Simsek, Michael H. Lubatkin, and John F. Veiga. 2008. Transformational Leadership's Role in Promoting Corporate Entrepreneurship: Examining the CEO-TMT Interface. Academy of Management Journal 51: 557-76. [CrossRef]

Liao, Jianwen, and Harold Welsch. 2005. Roles of social capital in venture creation: Key dimensions and research implications. Journal of Small Business Management 43: 345-62. [CrossRef]

Lopez-Cabrales, Alvaro, Mar Bornay-Barrachina, and Mirta Diaz-Fernandez. 2017. Leadership and dynamic capabilities: the role of HR systems. Personnel Review 46: 255-76. [CrossRef]

MacKenzie, Scott B., Philip M. Podsakoff, and Gregory A. Rich. 2001. Transformational and transactional leadership and salesperson performance. Journal of the Academy of Marketing Science 29: 115-34. [CrossRef] 
Miller, Danny. 1983. The correlates of entrepreneurship in three types of firms. Management Science 29: 770-91. [CrossRef]

Moriano, Juan A., Fernando Molero, Gabriela Topa, and Jean-Pierre Lévy Mangin. 2014. The influence of Transformational Leadership and Organizational Identification on Intrapreneurship. International Entrepreneurship and Management Journal 10: 103-19. [CrossRef]

Morris, Michael H., and Donald F. Kuratko. 2002. Corporate Entrepreneurship, 1st ed. Orlando: Harcout College Publishers.

Morrisette, Shelley, and William Oberman. 2013. Shifting Strategic Imperatives: A Stages of Leadership Perspective on the Adoption of Corporate Entrepreneurship. Journal of Applied Management and Entrepreneurship 18: 59-82. [CrossRef]

Mumford, Michael D., Ginamarie M. Scott, Blaine Gaddis, and Jill M. Strange. 2002. Leading creative people: Orchestrating expertise and relationships. The Leadership Quarterly 13: 705-50. [CrossRef]

Muralidharan, Etayankara, and Saurav Pathak. 2018. Sustainability, Transformational Leadership, and Social Entrepreneurship. Sustainability 10: 567. [CrossRef]

Nardelli, Giulia. 2017. Innovation dialectics: An extended process perspective on innovation in services. The Service Industries Journal 37: 31-56. [CrossRef]

Nemanich, Louise A., and Dusya Vera. 2009. Transformational leadership and ambidexterity in the context of an acquisition. The Leadership Quarterly 20: 19-33. [CrossRef]

OECD. 2004. Small Medium-Sized Enterprises in Turkey. Paris: Issues and Policies.

Öncer, Ayla Zehra. 2013. Investigation of The Effects of Transactional and Transformational Leadership on Entrepreneurial Orientation. International Journal of Business and Social Research 3: 153-66.

Pérez-Luño, Ana, Johan Wiklund, and Ramón Valle Cabrera. 2011. The dual nature of innovative activity: How entrepreneurial orientation influences innovation generation and adoption. Journal of Business Venturing 26: 555-71. [CrossRef]

Podsakoff, Philip M., and Dennis W. Organ. 1986. Self-reports in organizational research: Problems and prospects. Journal of Management 12: 531-44. [CrossRef]

Podsakoff, Philip M., Scott B. MacKenzie, Robert H. Moorman, and Richard Fetter. 1990. Transformational leader behaviors and their effects on followers' trust in leader, satisfaction, and organizational citizenship behaviors. The Leadership Quarterly 1: 107-42. [CrossRef]

Puffer, Sheila M., and Daniel J. McCarthy. 2008. Ethical turnarounds and transformational leadership: A global imperative for corporate social responsibility. Thunderbird International Business Review 50: 303-14. [CrossRef]

Quan, Le. 2015. Perceptions of Leadership Competencies and the Acquisition of Them by CEOs in Vietnamese Small Enterprises. Asian Social Science 11: 17-25. [CrossRef]

Ramos-González, Mª , Mercedes Rubio-Andrés, and Miguel Ángel Sastre-Castillo. 2017. Building Corporate Reputation through Sustainable Entrepreneurship: The Mediating Effect of Ethical Behavior. Sustainability 9: 1663. [CrossRef]

Roslan, Abdul Aziz. 2010. The Mediating Effects of Entrepreneurial Orientation on the Relationship Between Leadership Styles and Performance of SMEs in Malaysia. Ph.D thesis, Universiti Utara Malaysia, Kedah, Malaysia.

Ryan, James C., and Syed AA Tipu. 2013. Leadership Effects on Innovation Propensity: A Two-Factor Full Range Leadership Model. Journal of Business Research 66: 2116-29. [CrossRef]

Schmelter, Ralf, René Mauer, Christiane Börsch, and Malte Brettel. 2010. Boosting Corporate Entrepreneurship Through HRM Practices: Evidence from German SMEs. Human Resource Management 49: 715-41. [CrossRef]

Shen, Yuzhong, Chuanjing Ju, Tas Yong Koh, Steve Rowlinson, and Adrian J. Bridge. 2017. The impact of transformational leadership on safety climate and individual safety behavior on construction sites. International Journal of Environmental Research and Public Health 14: 45. [CrossRef] [PubMed]

Sosik, John J., Surinder S. Kahai, and Bruce J. Avolio. 1998. Transformational leadership and dimensions of creativity: Motivating idea generation in computer-mediated groups. Creativity Research Journal 11: 111-21. [CrossRef]

Su, Sophia, and Kevin Baird. 2017. The role of leaders in achieving organisational outcomes. Personnel Review 46: 593-607. [CrossRef]

Teng, Bing-Sheng. 2007. Corporate Entrepreneurship Activities through Strategic Alliances: A Resource-Based Approach toward Competitive Advantage. Journal of Management Studies 44: 119-42. [CrossRef] 
Tsai, Wenpin. 2001. Knowledge transfer in intraorganizational networks: Effects of network position and absorptive capacity on business unit innovation and performance. Academy of Management Journal 44: 996-1004. [CrossRef]

Venkatraman, Natarajan. 1989. Strategic Orientation of Business Enterprises: The Construct, Dimensionality, and Measurement. Management Science 35: 942-62. [CrossRef]

Vera, Dusya, and Mary Crossan. 2004. Strategic leadership and organizational learning. Academy of Management Review 29: 222-40.

Waldman, David A., and Leanne E. Atwater. 1994. The nature of effective leadership and championing processes at different levels in a R\&D hierarchy. The Journal of High Technology Management Research 5: 233-45.

Waldman, David A., Mansour Javidan, and Paul Varella. 2004. Charismatic leadership at the strategic level: A new application of upper echelons theory. The Leadership Quarterly 15: 355-80. [CrossRef]

Warland, Martin, and Heike Mayer. 2017. Peculiarities of public sector clients in service innovations. The Service Industries Journal 37: 105-24. [CrossRef]

Williams, Helen M., Sharon K. Parker, and Nick Turner. 2010. Proactively Performing Teams: The Role of Work Design, Transformational Leadership, and Team Composition. Journal of Occupational and Organizational Psychology 83: 301-24. [CrossRef]

Woodman, Richard W., John E. Sawyer, and Ricky W. Griffin. 1993. Toward a theory of organizational creativity. Academy of Management Review 18: 293-321.

Yang, Chung-Wen. 2008. The Relationships Among Leadership Styles, Entrepreneurial Orientation, and Business Performance. Managing Global Transitions 6: 257-75.

Zahra, Shaker. 1991. Predictors and financial outcomes of corporate entrepreneurship: An exploratory study. Journal of Business Venturing 6: 259-85. [CrossRef]

Zahra, Shaker. 1993a. A Conceptual Model of Entrepreneurship as Firm Behavior: A Critique and Extension. Entrepreneurship Theory and Practice 17: 5-21. [CrossRef]

Zahra, Shaker. 1996. Goverance, Ownership, and Corporate Entrepreneurship: The Moderating Impact of Industry Technological Opportunities. Academy of Management Journal 39: 1713-35. [CrossRef]

Zahra, Shaker A., and Gerard George. 2002. Absorptive Capacity: A Review, Reconceptualization, and Extension. Academy of Management Review 27: 185-203.

Zahra, Shaker A., Igor Filatotchev, and Mike Wright. 2009. How Do Threshold Firms Sustain Corporate Entrepreneurship? The Role of Boards and Absorptive Capacity. Journal of Business Venturing 24: 248-60. [CrossRef]

(C) 2018 by the authors. Licensee MDPI, Basel, Switzerland. This article is an open access article distributed under the terms and conditions of the Creative Commons Attribution (CC BY) license (http://creativecommons.org/licenses/by/4.0/). 